\title{
Nitric Oxide: Cytokine-regulation of nitric oxide in host resistance to intracellular pathogens
}

\author{
Shawn J. Green ${ }^{a, *}$, Libia F. Scheller ${ }^{b}$, Michael A. Marletta ${ }^{c}$, Matthew C. Seguin ${ }^{d}$, \\ Francis W. Klotz ${ }^{\text {d, Mike Slayter }}{ }^{\text {d }}$, Barbara J. Nelson ${ }^{\text {d }}$ and Carol A. Nacy ${ }^{\text {a }}$ \\ ${ }^{a}$ EntreMed, Inc., Rockville, MD, USA; ${ }^{b}$ University of Maryland School of Medicine, Baltimore, MD, USA; ${ }^{c}$ University of Michigan, \\ College of Pharmacy, Ann Arbor, MI, USA; ${ }^{d}$ Walter Reed Army Institute of Research, Washington, DC, USA
}

(Received 30 June 1994; accepted 26 August 1994)

Key words: Nitric oxide; TGF- $\beta$; CD8 ${ }^{+}$T cells; Malaria; Leishmania; BCG; Francisella; Hepatocyte; Macrophage

\section{Summary}

To discover how nitric oxide (NO) synthesis is controlled in different tissues as cells within these tissues combat intracellular pathogens, we examined three distinctively different experimental murine models designed for studying parasite-host interactions: macrophage killing of Leishmania major; nonspecific protection against tularemia (Francisella tularensis) by $M y-$ cobacterium bovis (BCG); and specific vaccine-induced protection against hepatic malaria with Plasmodium berghei. Each model parasite and host system provides information on the source and role of NO during infection and the factors that induce or inhibit its production. The in vitro assay for macrophage antimicrobial activity against $L$. major identified cytokines involved in regulating NO-mediated killing of this intracellular protozoan. L. major induced the production of two competing cytokines in infected macrophages: (1) the parasite activated the gene for tumor necrosis factor (TNF), and production of TNF protein was enhanced by the presence of interferon-gamma (IFN- $\gamma$ ). TNF then acted as a autocrine signal to amplify IFN- $\gamma$-induced production of NO; and (2) the parasite upregulated production of transforming growth factor-beta (TGF- $\beta$ ), which blocked IFN- $\gamma$-induced production of NO. Whether parasite-induced TNF (parasite destruction) or TGF- $\beta$ (parasite survival) prevailed depended upon the pres-

\footnotetext{
* Corresponding author: S.J. Green, EntreMed, Inc., Rockville, MD,
} USA. ence and quantity of IFN- $\gamma$ at the time of infection. The relationship between NO production in vivo and host resistance to infection was demonstrated with $M$. bovis (BCG). These studies confirmed that both IFN- $\gamma$ and TNF are required for induction of NO-mediated nonspecific host defense in vivo. The presumed source of NO in these studies was the activated macrophage, however, other cells infected with parasites can also be stimulated to produce NO. In studying acquired immunity to malaria induced by irradiated sporozoites, we found that IFN- $\gamma$ provided by malaria-specific $\mathrm{CD} 8^{+} \mathrm{T}$ cells stimulated sporozoite-infected hepatocytes to produce NO for destruction of either infected hepatocytes or the parasite, $P$. berghei, within these cells.

\section{Introduction}

The enzyme that drives the oxidation of L-arginine to yield NO and the by-product L-citrulline is NO synthase (NOS), a flavin-containing hemoprotein $[1,2]$. At least three different NOS isoforms are identified, and they fall into two distinct types, constitutive and inducible [3]. The constitutive enzyme produces NO in response to agonists that elevate intracellular calcium; the result is an immediate, yet transient synthesis of low NO amounts. Stimulation of the constitutive pathway is associated with regulatory or housekeeping tasks, such as maintaining vascular tone [4]. The inducible NOS isoform (iNOS) is expressed in a variety of tissue and cell types $[5,6]$. The iNOS found in macrophages and 
hepatocytes begins to produce NO several hours after cytokine stimulation $[5,6]$, and activation of the iNOS is at the transcriptional level [7-9]. Once expressed, high quantities (nM to $\mu \mathrm{M}$ amounts) of NO are produced in culture for days. High levels of NO can be cytotoxic, and a number of different microorganisms are susceptible to these levels of NO [10]. The actions of NO cytotoxic or regulatory - are determined by the magnitude and duration of NO synthesis.

Our interest is in the cytokines and events that are required to induce NO-mediated antimicrobial activity and control iNOS expression in vivo. We document the antimicrobial effects of cytokine-induced NO synthesis and the mechanisms that regulate this event during an immune response to intracellular pathogens that are physiologically and phylogeneticially distinct from one another: Leishmania, Mycobacteria, and Francisella, which all reside within the macrophage, and Plasmodia sporozoites, which infect hepatocytes.

\section{Results and Discussion}

\subsection{Leishmania regulate macrophage NO synthase by induction of TNF and TGF- $\beta$}

Nitrogen oxidation of L-arginine is the mechanism by which IFN- $\gamma$-stimulated murine macrophages destroy and eliminate Leishmania amastigotes [11]. Involvement of this effector pathway is now confirmed by different methodologies in several labs [for review, see 12]: use of competitive inhibitor of L-arginine, $\mathrm{N}^{\mathrm{G}}$ monomethyl-L-arginine ( ${ }^{G}$ MMLA), to block synthesis of NO; denying infected cells the iNOS substrate (L-arginine) through the use of L-arginine-deficient media or arginase depletion of L-arginine; and demonstrating the correlation of nitrite $\left(\mathrm{NO}_{2}^{-}\right)$and nitrate $\left(\mathrm{NO}_{3}^{-}\right)$ (stable oxidative NO endproducts) accumulation with the killing of amastigotes by activated macrophages. In addition, elevated levels of urinary $\mathrm{NO}_{3}^{-}$correlated with resistance to infection, while susceptible mice failed to produce $\mathrm{NO}_{3}^{-}$during the infectious process, and in vivo administration of $\mathrm{N}^{\mathrm{G}}$ MMLA blocked elevated urinary $\mathrm{NO}_{3}^{-}$excretion in resistant mice. When injected at the cutaneous leishmanial lesion site or given orally, $\mathrm{N}^{\mathrm{G}}$ MMLA caused an increase in number of parasites and led to amastigote dissemination in visceral tissues $[13,14]$.

Maximal expression of iNOS depends upon multiple signals delivered to macrophages in a defined sequence. Resident peritoneal macrophages from untreated mice exposed only to IFN- $\gamma$ release little $\mathrm{NO}_{2}$ and are not cytotoxic; however, IFN- $\gamma$-treated cells respond to small quantities of a second signal such as LPS for cytotoxic activity and production of $\mathrm{NO}_{2}^{-}$. As analyzed by immunofluorescence, iNOS is dramatically elevated in the cytosol of macrophages treated with IFN- $\gamma$ and LPS, whereas very little is detected in a small subset of macrophages treated with either IFN- $\gamma$ or LPS alone (Fig. 1). The activity of LPS as a second signal for NO production can be partially reduced, although not completely, by antibody to TNF, and TNF itself is an effective second signal [15-17].

For induction of macrophage antileishmanial activity, we find an apparent paradox in the multi-step cytokine regulation of cytotoxic activity: IFN- $\gamma$ alone is sufficient. Resident macrophages infected with $L$. major amastigotes and then treated with IFN- $\gamma$ produce high levels of NO and kill the intracellular parasite without the addition of a secondary signal such as LPS or exogenous TNF [18]. The second signal function of amastigotes infection is not due to contaminant LPS, nor is the process simply one of phagocytosis. Infection of IFN- $\gamma$-stimulated macrophages with viable amastigotes is critical for NO production [18]. Does the parasite itself play an active role in stimulating the effector activity responsible for its destruction?

In an effort to identify cellular consequences of infection, we determined that $L$. major amastigotes activate the gene and induce the synthesis and release of TNF. Within 2-4 hours after infection, macrophages begin to secrete TNF into culture medium. The amount of TNF produced by infected cells increased 10 -fold in the presence IFN- $\gamma$ [18]. IFN $\gamma$-treated macrophages cultured with and without LPS also release higher levels of TNF after the addition of promastigotes of $L$. enrietti and amastigotes of $L$. donovani. $[19,20]$. These observations are especially interesting in light of early reports that document the synergistic interaction of TNF and IFN $\gamma$ for induction of macrophage cytotoxic activity and NO release [15]. TNF is involved for maximal expression of cytotoxic levels of NO, since IFN- $\gamma$ treated macrophages infected by amastigotes in the presence of monoclonal anti-TNF failed to synthesize NO as shown by immunoblot analysis for enzyme and $\mathrm{NO}_{2}^{-}$production when assessed for in culture fluid (Fig. 2). In a dose dependent fashion, anti-TNF treatment blocked intracellular killing of Leishmania by IFN- $\gamma$-treated macrophages [18].

There is now a broad consensus that the principal effector mechanism of murine macrophages for destruction of Leishmania is induction of nitrogen oxidation of L-arginine by IFN- $\gamma$ and TNF. It is puzzling that the Leishmania actually participates in its own destruction by stimulation of TNF, an endogenous second signal for NO synthesis: why is the parasite, naturally concerned with its own survival, so cooperative in initiating the 
host's defense mechanism? In our efforts to understand this interaction, we discovered that the parasite does indeed subvert the deterimental consequences of its own infectious processs, and does so by using, again, the host cell's own constitutively-produced product: TGF- $\beta$. As shown in Table 1, low levels of TGF- $\beta$ are found in the culture fluids of murine peritoneal macrophages. Infection of these cells with amastigotes of $L$. major induces a $10-100$-fold increase in the release of this cytokine over a period of $2-3$ days: this is a quantity sufficient to totally suppress macrophage activation [21]. If cultures are incubated with TGF- $\beta$ prior to the addition of IFN- $\gamma$, intracellular killing of amastigotes by NO is blocked (Table 2) [21].

Thus, the parasite induces the production of two competing cytokines in infected macrophages: TNF, which acts as an autocrine signal to amplify IFN- $\gamma$-induced production of NO, and TGF- $\beta$, which acts as an autocrine signal to block IFN- $\gamma$-induced production of NO. Implicit in the competing agendas of these cy- tokines is the issue of timing: exposure of the macrophage to the appropriate cytokines, at the proper time, is requisite for clearance of the intracellular parasite (Fig. 3). If the signals are delivered out of sequence, cytotoxic activity, iNOS activity (Table 3 ), and production of $\mathrm{H}_{2} \mathrm{O}_{2}$ are greatly diminished $[17,22]$. Several lines of evidence suggest a central role for TNF in this phenomenon [17,22-24]. For example, pre-exposure to trace levels of LPS reduces TNF receptor expression and TNF mRNA expression [23]. We know that pre-exposure of cells to LPS [17] or Leishmania [unpublished] for a prolonged period of time causes macrophages to become refractory to IFN- $\gamma$-induced activation, and this is likely due to the production of autocrine-active TGF- $\beta$, which may downregulate TNF mRNA and activity $[23,25]$. The competition between cytokines for control of cellular function may explain the persistence, but eventual clearance of parasites without therapeutic intervention in patients with cutaneous L. major disease.
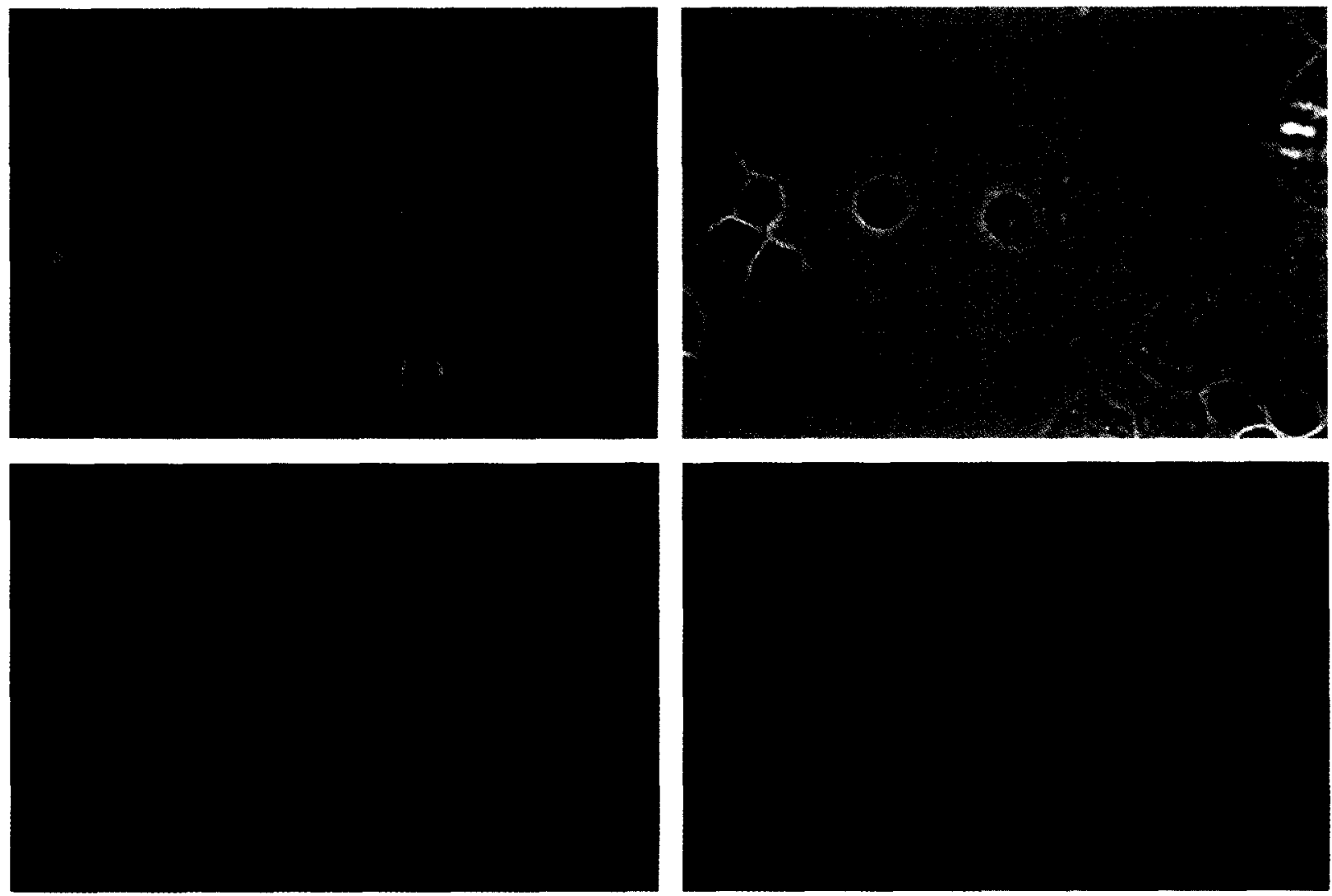

Fig. 1. Immunofluorescence analysis of iNOS. Resident peritoneal macrophages stimulated with (A) $10 \mathrm{U} / \mathrm{ml} \mathrm{IFN- \gamma} \mathrm{and} 10 \mathrm{ng} / \mathrm{ml} \mathrm{LPS} \mathrm{or} \mathrm{(A)}$ IFN- $\gamma$ alone. After $16 \mathrm{~h}$ at $37^{\circ} \mathrm{C}$, cell smears were prepared and examined microscopically under bright-field (upper panels) or with epifluorescence (lower panels) after staining with rabbit polyclonal antibody to iNOS. FITC conjugated goat antibodies against rabbit IgG were used to react with tissue bound anti-iNOS antibody. 


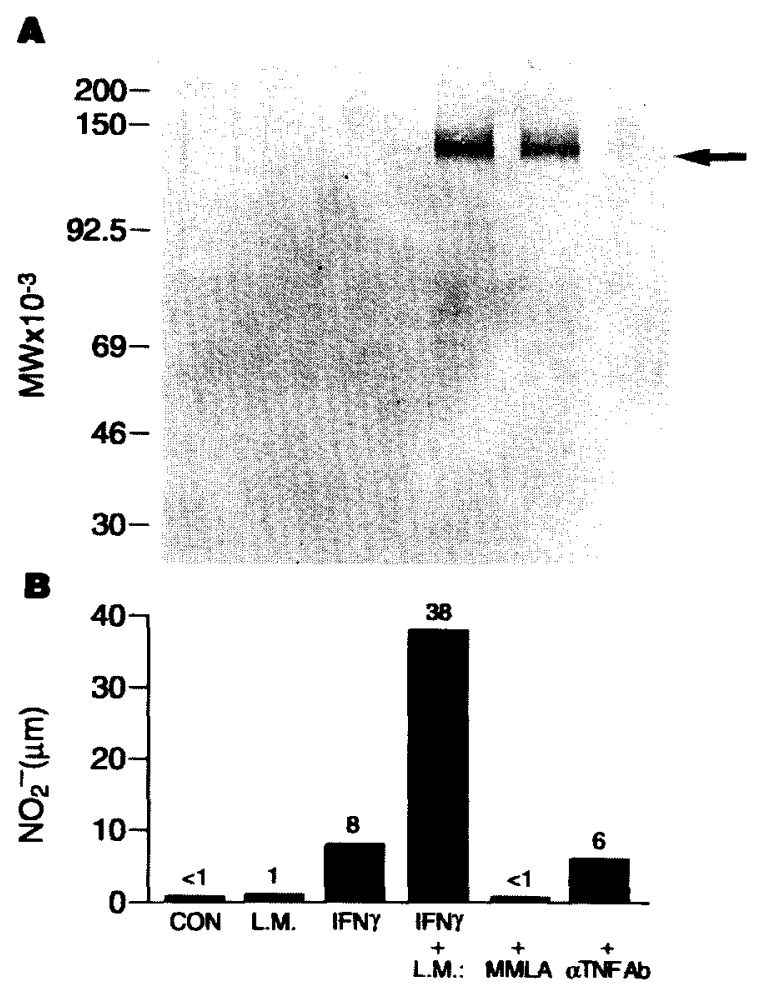

Fig. 2. iNOS immunoblot and $\mathrm{NO}_{2}^{-}$levels of macrophages. (A) $10^{6}$ resident peritoneal macrophages were cultured alone (CON), infected with $L$. major amastigotes (L.M.) treated with $10 \mathrm{U} \mathrm{IFN- \gamma}$ alone (IFN $\gamma$ ) or with $10^{5} L$. major (IFN $\gamma+$ L.M.) in the presence of 0.05 mM N ${ }^{\mathrm{G}}$ MMLA (IFN $\gamma+$ L.M. + MMLA) or $20 \mathrm{mg}$ anti-TNF antibody (IFN $\gamma+$ L.M. $+\alpha$ TNFAb). After $24 \mathrm{~h}$ at $37^{\circ} \mathrm{C}, 5 \% \mathrm{CO}_{2}$, cells were prepared for SDS-PAGE, transferred to nitrocellulose and probed with anti-rabbit sera to iNOS. Arrow indicates iNOS. Maximal expression of iNOS protein is detected in cells infected with $L$. major and stimulated with IFN $\gamma$ (in the absence or presence of $\mathrm{N}^{\mathrm{G}} \mathrm{MMLA}$ ), while IFN $\gamma$ treatment alone stimulated low level expression, and infection by Leishmania had no stimulator effect. The addition of a neutralizing antibody to TNF, dramatically reduced the expression of iNOS protein in IFNg and Leishmania treated cells. (B) $\mathrm{NO}_{2}^{-}$levels found in the culture fluid. $\mathrm{NO}_{2}$-production correlated with the expression of iNOS protein.

TABLE 1

LEVELS OF TGF $\beta$ IN CULTURE FLUID OF MACROPHAGES INFECTED WITH AMASTIGOTES OF L. MAJOR

Resident peritoneal cells or inflammatory cells elicited by proteose peptone were cultured alone or in the presence of $L$. major amastigote (1 per macrophage) at $37^{\circ} \mathrm{C}$ in $5 \% \mathrm{CO}_{2}$ in moist air for 24 and $72 \mathrm{~h}$. TGF $\beta$ was tested for in the culture fluid by ELISA using both turkey and rabbit polyclonal antibodies [21].

\begin{tabular}{lcr}
\hline Source of macrophage: & \multicolumn{2}{c}{ TGF $\beta(\mathrm{pg} / \mathrm{ml})$ at: } \\
\cline { 2 - 3 } & $24 \mathrm{~h}$ & $72 \mathrm{~h}$ \\
\hline Resident cells & 10 & 30 \\
$\quad$ + amastigotes & 650 & 1080 \\
Inflammatory cells & 40 & 30 \\
$\quad$ + amastigotes & 460 & 970 \\
\hline
\end{tabular}

3.2. IFN- $\gamma$ and TNF are regulatory cytokines in nonspecific protection against Francisella and host response to Mycobacteria infection

Mycobacterium bovis BCG inoculation of mice leads to a nonlethal, self-limiting infection, even in genetically susceptible animals. The very nature of this infection provides us with a model to examine some of the same issues and interests addressed previously in vitro. For example, mice inoculated with BCG secrete up to 200 times more urinary $\mathrm{NO}_{3}^{-} 8-10$ days after infection than uninfected animals, and elevated urinary $\mathrm{NO}_{3}^{-}$ persists for months, a consequence of the chronic nature of this infection. The source of elevated urinary $\mathrm{NO}_{3}^{-}$ in BCG infected mice is likely from iNOS of activated macrophages [26-28]. When $\mathrm{N}^{\mathrm{G}} \mathrm{MMLA}$ is administrated orally to $\mathrm{BCG}$-infected mice, $\mathrm{NO}_{3}^{-}$excretion is inhibited by $90 \%$ [27]. Here, we are interested in the relationship between urinary $\mathrm{NO}_{3}^{-}$and host resistance: what are the mechanisms and consequences of NO induction?

The large urinary $\mathrm{NO}_{3}^{-}$excretion accompanying $\mathrm{BCG}$ administration in mice correlated with macrophage activation and non-specific resistance to a heterologous microorganism, Francisella tularensis, an extremely lethal gram negative bacterium [28]. With an approximately 2-fold increase in urinary $\mathrm{NO}_{3}^{-}$level over the first 3 days after BCG treatment, the mean time to death from Francisella increased from 4 days in mice challenged 1 day after $\mathrm{BCG}$ to 9 days in mice challenged 3 days after BCG. On day 4 after BCG exposure, mice were fully protected against a lethal inoculum of Francisella and continued to generate greater amounts of $\mathrm{NO}_{3}^{-}$in a linear fashion until a plateau was reached by 8-12 days. Macrophages removed from BCG infected mice on day 8 exhibited potent antimicrobial activity, which could be blocked with $\mathrm{N}^{G}$ MMLA. Oral adminis-

TABLE 2

MACROPHAGE MICROBICIDAL ACTIVITY AND NO DUCTION: EFFECT OF TGF $\beta$

Resident peritoneal cells were pretreated with $50 \mathrm{ng} / \mathrm{ml} \mathrm{TGF} \beta$ for 2 $\mathrm{h}$, and then infected with amastigotes ( 1 per macrophage) and treated with IFN- $\gamma$. After $72 \mathrm{~h}$, cell smears were prepared and the number of infected cells were assessed. $\mathrm{NO}_{2}^{-}$levels were measured in culture fluid using the Greiss reagents.

\begin{tabular}{lll}
\hline $\begin{array}{l}\text { Macrophage } \\
\text { treated with: }\end{array}$ & $\begin{array}{l}\text { \% microbicidal activity } \\
\text { against amastigotes } \\
\text { of } L . \text { major }\end{array}$ & $\begin{array}{l}\mathrm{NO}_{2}^{-} \\
(\mu \mathrm{M} / 72 \mathrm{~h})\end{array}$ \\
\hline Medium & 0 & $<1$ \\
+ TGF $\beta$ & 0 & $<1$ \\
IFN $\gamma$ & 67 & 38 \\
+ TGF $\beta$ & 9 & 5 \\
\hline
\end{tabular}




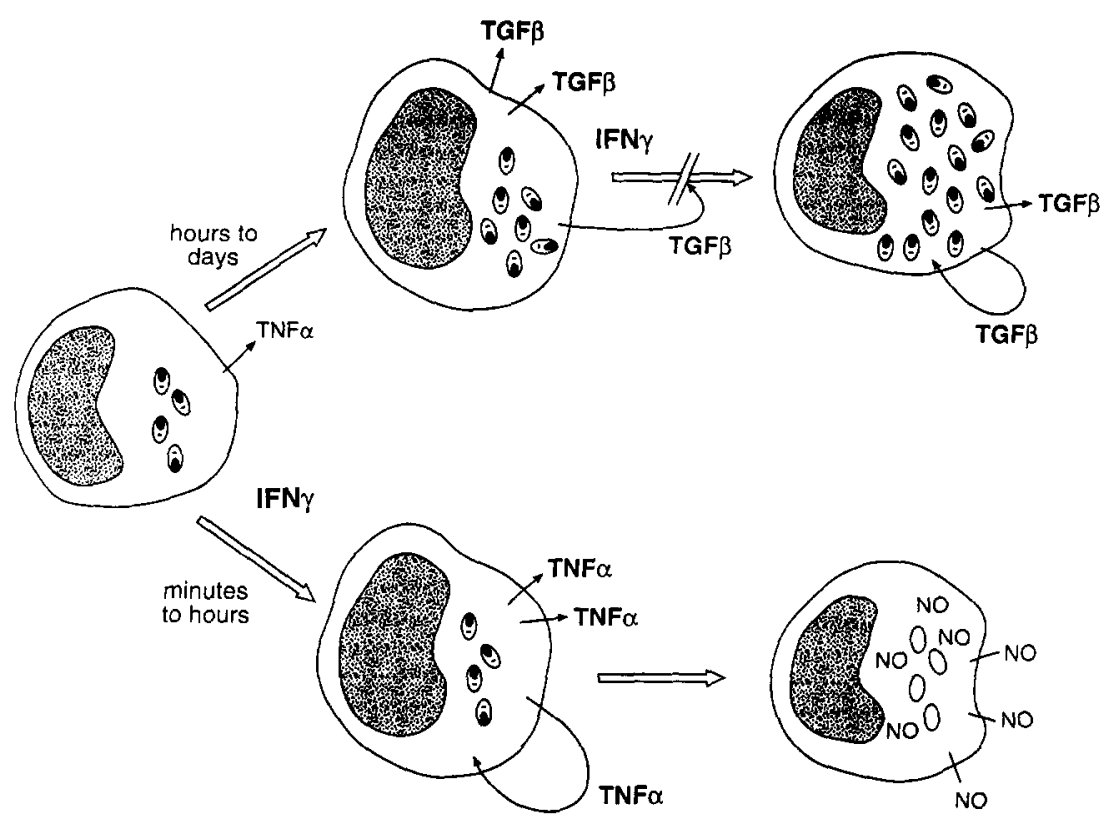

Fig. 3. Competing agents of Leishmania induced TNF and TGFb. The race for survival hinges on the differential production of parasite-induced TGF $\beta$ and TNF. The presence of IFN- $\gamma$ determines which parasite-induced cytokines prevails. In the absence of IFN $\gamma$ (pathway on top), parasites induce TGF $\beta$, preventing induction of NO that results in an increase in parasite burden. In contrast, in the presence of IFN- $\gamma$ (pathway on bottom) parasite induced TNF is increased to a threshold level to act in a synergistic fashion with IFN- $\gamma$ to induce cytotoxic levels of NO that results in a decrease in parasite burden.

tration of $\mathrm{N}^{\mathrm{G}}$ MMLA reduced urinary $\mathrm{NO}_{3}^{-}$output and exacerbated the disease, with a $3 \mathrm{log}$ increase in Francisella growth in the peritoneum [28].

To examine the role of IFN- $\gamma$ and TNF in vivo, BCG infected mice were treated with monoclonal antibodies to IFN- $\gamma$ or TNF- $\alpha$ on day 8 , the peak of urinary $\mathrm{NO}_{3}^{-}$excretion in $\mathrm{BCG}$ infected mice [27]. Levels of urinary $\mathrm{NO}_{3}^{-}$dropped precipitously over the next several days in these animals, and $100 \%$ of the mice treated with anti-cytokine antibody succumbed to

TABLE 3

CYTOTOXIC ACTIVITY BY MACROPHAGES: EFFECTS OF PRETREATMENT WITH LPS

Adherent peritoneal macrophages were treated with $10 \mathrm{U} / \mathrm{ml} \mathrm{IFN}-\gamma$ or $10 \mathrm{ng} / \mathrm{ml}$ LPS for $4 \mathrm{~h}$ (arrow), washed, and then treated with either IFN- $\gamma$ or LPS. Pretreatment with LPS greatly reduces IFN- $\gamma$ induced $\mathrm{NO}_{2}^{-}$and cytotoxicity. Levels of $\mathrm{NO}_{2}^{-}$in culture fluid were estimated by using the Greiss reagents. Cytotoxicity was estimated by release of radiolabel at $48 \mathrm{~h}$ and expressed as percent of SDS total counts [17]

\begin{tabular}{lll}
\hline $\begin{array}{l}\text { Macrophage } \\
\text { treated with: }\end{array}$ & $\begin{array}{l}\mathrm{NO}_{2}^{-} \\
(\mu \mathrm{M} / 48 \mathrm{~h})\end{array}$ & $\begin{array}{l}\text { tumor cytotoxicity } \\
(\% \text { total counts })\end{array}$ \\
\hline medium & $<\mathbf{1}$ & 20 \\
IFN $\gamma$ & 4 & 25 \\
IFN $\gamma \rightarrow$ LPS & $\mathbf{5 4}$ & $\mathbf{8 5}$ \\
LPS & 2 & 27 \\
LPS $\rightarrow$ IFN $\gamma$ & $\mathbf{8}$ & $\mathbf{3 0}$ \\
\hline
\end{tabular}

a subsequent lethal infection with $F$. tularensis on day 10 ; in contrast, mice that did not receive anti-IFN- $\gamma$ or anti-TNF- $\alpha$ antibodies survived the challenge. Likewise, administration of anti-IFN- $\gamma$ and anti-TNF- $\alpha$ antibodies at the time of BCG inoculation resulted in a 1-2 week delay in excretion of $\mathrm{NO}_{3}^{-}$compared with BCG treatment alone, and protection against $F$. tularensis affored by BCG was dramatically reduced: 200000 fold decrease in the lethal dose for $F$. tularensis was observed in BCG-infected mice treated with monoclonal antibody to either IFN- $\gamma$ or TNF [28]. Examination of the histopathology of liver from mice treated with $B C G$ and anticytokine monoclonal antibody revealed diffuse multifocal necrosis caused by $F$. tularensis and a complete absence of BCG-induced microgranuloma formation (Fig. 4C). In contrast, BCG-treated animals that did not receive anticytokines exhibited BCG-induced microgranuloma formation and no detectable $F$. tularensis-associated necrosis (Fig. 4B). With the natural clearance of the neutralizing antibodies, both non-specific protection and elevated $\mathrm{NO}_{3}^{-}$ levels were restored.

The administration of anticytokine antibodies at the time of BCG inoculation most likely affected the induction of immunity to BCG itself. As shown in Fig. 4, BCG microgranulomas failed to form after anticytokine treatment. Indeed, such treatment also enhanced $M y$ cobacteria numbers in spleen [29]. Consistent with the 

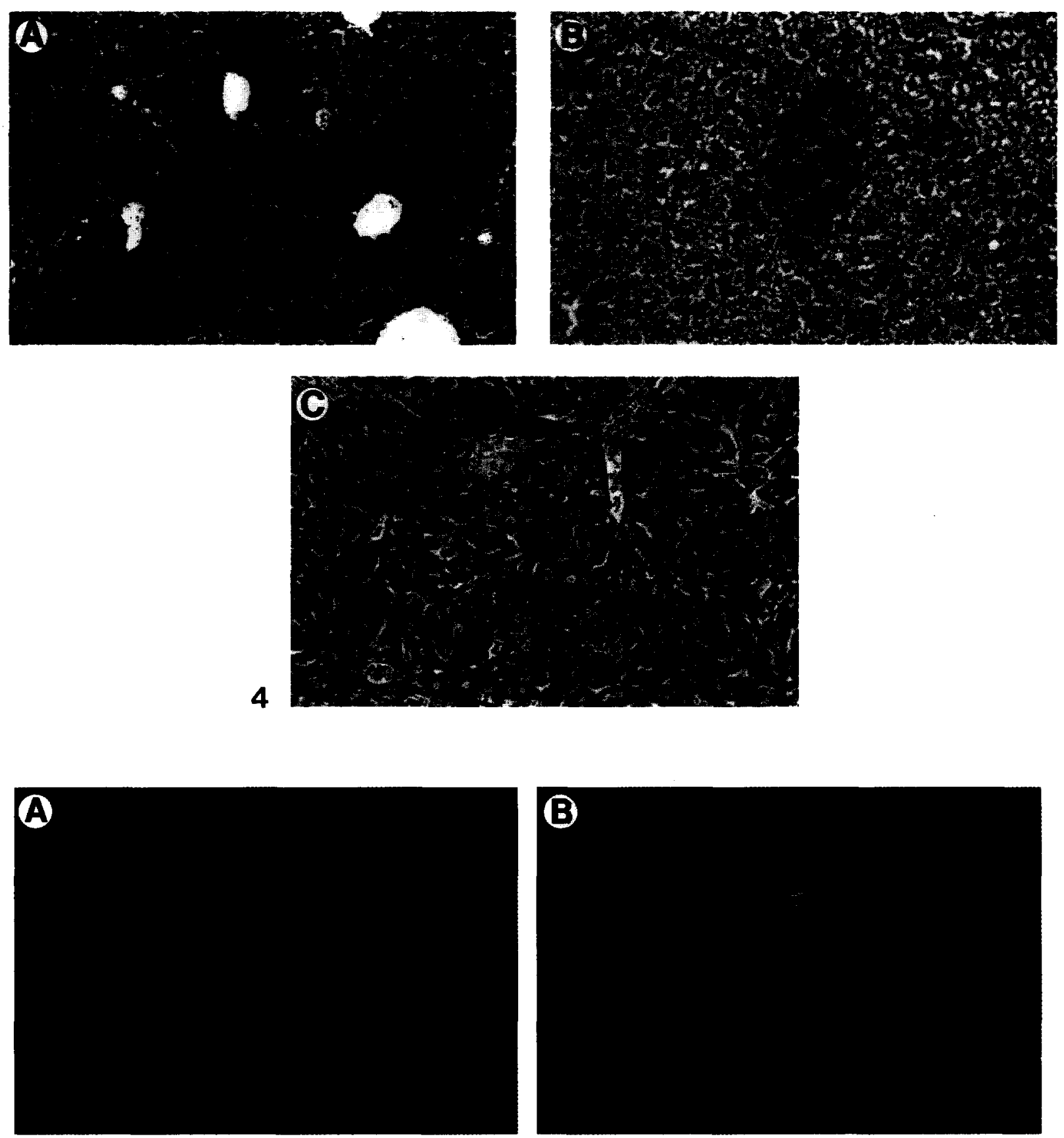

B

5

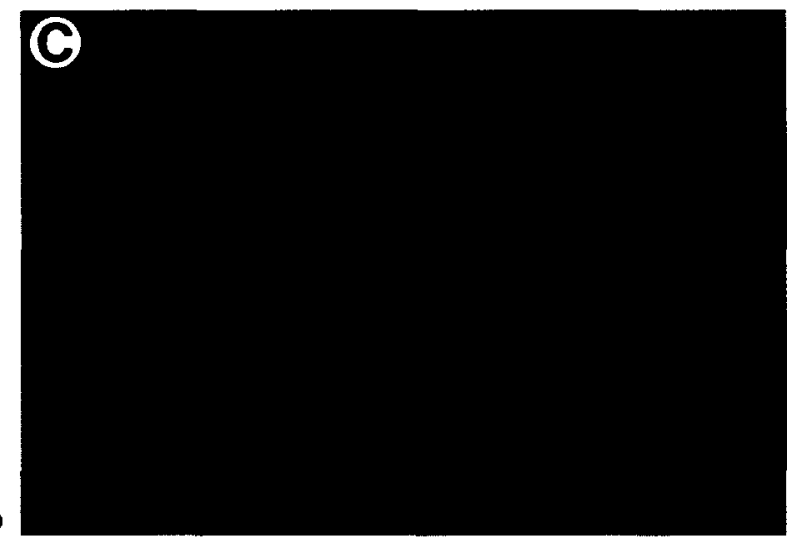

(D) 
in vivo cytokine depletion studies, mice generated with a targeted disruption of IFN- $\gamma$ and IFN- $\gamma$ receptor genes also failed to synthesize NO, as assessed by the lack of elevated urinary nitrate excretion in BCG infected mice [30,31, unpublished data]. Furthermore, BCG infection was more severe and extensive than in infected wild-type mice.

More recent inquiries into understanding how IFN- $\gamma$ activate inducible NOS revealed that interferon regulatory factor-1 (IRF-1) is essential. Within the iNOS promoter sequence, two adjacent IRF binding motifs were recently identified [32,33]. IRF-1 is induced by IFNs, and this factor binds to sites within the promoter of IFN $\alpha$ and $\beta$ and several IFN- $\gamma$-inducible genes resulting in the transcriptional activation of these genes [33]. Mice generated with homozygous targeted disruption of the IRF-1 gene were used to analyze the role IRF-1 in NO generation and resistance to BCG. BCG infected mice deficient of IRF-1 gene fail to generate NO, and the ability to eliminate BCG was dramatically impaired. IFN- $\gamma$ and LPS or TNF failed to induce NO activity in macrophages from mice lacking IRF-1 [33]. It is tempting to speculate that the lack of NO generation by macrophages from IRF-1 deficient, IFN- $\gamma$ receptorless mice, or IFN- $\gamma$ and TNF depleted mice is responsible for the more severe course of BCG infection.

In our quest to identify how NO is controlled in activated macrophages combating intracellular pathogens, we learned that other cells are equally competent to respond to cytokines and synthesis nitric oxide as an effector molecule. Hepatocytes in both rodent and man express iNOS activity in response to cytokines [34]. Like the macrophage, the hepatocyte is a host cell of an intracellular parasite - malaria sporozoite.

Fig. 4. Histopathology of liver from mice treated with BCG and anti-TNF. Liver from mice 4 days (A) after intraperitoneal injection of $10^{3} F$. tularensis; (B) after $F$. tularensis challenge that was previously exposed to $\mathrm{BCG}$; or $(\mathrm{C})$ after $F$. tularensis challenge which was exposed to BCG and anti-TNF (note: diffuse multifocal necrosis and DIC caused by $F$. tularensis and a complete absence of BCG-induced microgranuloma formation).

Fig. 5. Immunofluorescence analysis of $P$. berghei infected liver. Tissue from (A and B) immunized and (C and D) non-immunized rats at $31 \mathrm{~h}$ after sporozoite challenge were assessed for immunoreactivity to iNOS and malaria. Parasitized hepatocytes were identifed by their reactivity with $1 / 1600$ diluted mouse antisera against Pfhsp70 (A and C) and iNOS was localized (B and D) with 1/400 diluted rabbit antisera against purified mouse macrophage iNOS. TRITC conjugated goat antibodies against mouse IgG and FITC conjugated goat antibodies against rabbit IgG were used to react with tissue bound antibodies.
3.3. Acquired immunity to malaria is mediated by effectors of the innate response: role of $C D 8^{+} T$ cells, $I F N-\gamma$, and NO

Prior exposure to irradiated-sporozoites confers protective immunity to malaria $[35,36]$. This immunity is directed against liver stage malaria, and does not protect against blood stage malaria. To determinine if NO participates in this protective response, immunized animals were treated orally with aminoguanidine or $N^{G}$ MMLA at the time of challenge and continued for 4 days. Immunized animals given $\mathrm{N}^{G}$ MMLA displayed parasitema, which suggests that liver stage protection is dependent upon the generation of NO $[37,38]$. This is consistent with previous reports demonstrating that IFN- $\gamma$-stimulated hepatocytes inhibit the growth of malaria sporozoites in culture by generating NO $[39,40]$. To assess whether NO is produced in livers of protected animals, reverse transcription polymerase chain reaction analysis revealed that iNOS mRNA was present $24 \mathrm{~h}$ after challenge in immunized animals, while little, if any, was present in non-immunized [38].

Immunity directed against intrahepatic parasites involves T cells and IFN- $\gamma$, which prevent maturation of liver or exoerythrocytic stages and subsequent blood infection $[41,42]$. Treatment with anti-IFN- $\gamma$ antibodies or depletion of $\mathrm{CD}^{+} \mathrm{T}$ cells, not $\mathrm{CD}^{+} \mathrm{T}$ cells, significantly reduced iNOS mRNA and protection to challenge [38]. These results show that both $\mathrm{CD}^{+} \mathrm{T}$ cells and IFN- $\gamma$ are important components in the regulation of iNOS in liver which contributes to the protective response of mice immunized with irradiated sporozoites. Therefore, $\mathrm{CD} 8^{+} \mathrm{T}$ cells may participate both as effector cells, cytotoxic $\mathrm{T}$ lymphocytes, and facilitate the protective response by providing a source of IFN- $\gamma$ [38].

Antisera to malaria heat shock protein (PfHSP70) and iNOS identified the source of NO and the location of the parasite in liver after challenge with viable sporozoites (Fig. 5). Immunofluorescence analysis of parasitized livers demonstrates that (l) iNOS was restricted to infected hepatocytes, not Kupffer and endothelial cells; and (2) a higher proportion of infected hepatocytes express iNOS in immunized rats compared to naive animals after challenge. iNOS reactivity increased from $<2 \%$ at $15 \mathrm{~h}$ after sporozoite challenge in immunized rats to $18 \%$ by $24 \mathrm{~h}$ and reached $81 \%$ by $31 \mathrm{~h}$. In contrast, $<5 \%$ of the infected hepatocytes displayed iNOS activity in the naive animals after challenge.

The molecular mechanisms by which NO exerts antimicrobial activity are not yet identified, although there are a number of postulated targets. By studying macrophage mediated tumor injury, Hibbs and co- 
workers previously demonstrated that tumor cells cocultured with activated macrophages released iron, and the loss of iron correlated with a decrease in cellular respiration [for review, see 5]. This decrease in respiration was associated with elevated levels of NO produced by activated macrophages. The molecular targets were subsequently identified as the $4 \mathrm{Fe}-4 \mathrm{~S}$ prothetic groups associated with complexes I and II in the electron transport chain and aconitase in the Krebs cycle. Inactivation of these enzymes by NO correlated with the formation of nitrosyl-Fe complexes. Other molecular targets have since been identified which include the non-heme subunit of ribonucleotide reductase, the rate limiting enzyme for DNA replication, which complexes with NO [for review, see 12]. In the presence of superoxide anion, the highly toxic peroxynitrite is formed a potent antimicrobial agent. NO can also couple with cysteine to form nitrothiols which themselves reportedly display antimalaria activity. As we begin to understand more about cytokine regulation of NO-secreting cells and the role of NO in destruction of infectious agents, we may be able to design strategies to selective up-regulate NO in infected cells.

\section{Acknowledgements}

M.A.M. gratefully acknowledges support from NICA26731.

\section{References}

[1] White, K.A. and Marletta, M.A. (1992) Biochem. 311, 6627.

[2] Stuehr, D.J. and Ikeda-Saito, M. (1992) J. Biol. ('hem. 267, 20547.

[3] Stuehr, D.J. and Griffith, O.W. (1992) Adv. Enzymol. Mol. Biol. $65,287$.

[4] Moncada, S. (1992) Acta Physiol. Scand. 145, 201.

[5] Nathan, C.F. and Hibbs, J.B., Jr. (1991) Current Opinion İmmunol. 3, 65 .

[6] Nathan, C.F. (1992) FASEB 6, 3051.

[7] Lyons, C.R., Orloff, G.J. and Cunningham, J.M. (1992) J. Biol. Chem. 267, 6370.

[8] Xie, Q.W., Cho, H.J., Calaycay, J., Mumford, R.A., Swiderek, K.M., Lee, T.D., Ding, A., Troso, T. and Nathan, C. (1992) Science 256, 225.

[9] Lowenstein, C.J., Glatt, C.S., Bredt, D.S., Synder, S.H. (1992) Proc. Natl. Acad. Sci. USA 89, 67111.

[10] Green, S.J. and Nacy, C.A. (1993) Curr. Opinion Infect. Dis. 6, 384.

[11] Green, S.J., Meltzer, M.S., Hibbs, J.B., Jr. and Nacy, C.A. (1990) J. Immunol. 144, 278

[12] Green, S.J., Nacy, C.A. and Meltzer, M.S. (1991) J. Leuk. Biol. 50,93 .
[13] Liew, F.Y., Millott, S., Parkinson, C., Palmer, R.M.J. and Moncada, S. (1990) J. Immunol. 144, 4707.

[14] Evans, T., Thai, L., Granger D.L. and Hibbs, J.B., Jr. (1993) J. Immunol. 151, 907.

[15] Drapier, J.C., Wietzerbin, J., Hibbs, J.B., Jr. (1988) Eur. J. Immunol. 18, 1587.

[16] Ding, A.J., Nathan, C.F. and Stuehr, D.J. (1988) J. Immunol. $141,2407$.

[17] Green, S.J., Nacy, C.A., Morrison, D. and Meltzer, M.S. (1992) J. Immunol. 149, 2069.

[18] Green, S.J., Crawford, R.M., Hockmeyer, J.T., Meltzer, M.S and Nacy, C.A. (1990) J. Immunol. 145, 4294.

[19] Corradin, S.B. and Mauel, J. (1991) J. Immunol. 146, 279.

[20] Roach, T.I.A., Kiderlen, A. and Blackwell, J.M. (1992) Infect. Immun.

[21] Nelson, B.J., Ralph, P., Green, S.J. and Nacy, C.A. (1991) J. Immunol. 146, 1849.

[22] Ding, A.H. and Nathan, C.F. (1987) J. Immunol. 139, 1971.

[23] Chantry, D., Turner, M., Abney, E. and Feldman, M. (1989) J. Immunol. 142, 4929.

[24] Takasuka, N., Tokunaga, I. and Akagawa, K.S. (1991) J. Immunol. 146, 3824.

[25] Bogdan, C. and Nathan, C. (1993) Ann. NY Acad. Sci. 685, 713.

[26] Stuehr, D.J. and Marletta, M.A. (1985) J. Immunol. 139, 518.

[27] Granger, D.L., Hibbs, J.B., Jr. and Broadnax, L.M. (1992) J. Immunol. 146, 1294.

[28] Green, S.J., Nacy, C.A., Schreiber, R.D., Granger, D.I., Crawford, R.M., Meltzer, M.S. and Fortier, A.H. (1993) Infect Immun. 61, 689.

[29] Kindler, V., Sappino, A.-P., Grau, G.E., Piguet, P.-H. and Vas. salli, P. (1989) Cell 56, 731.

[30] Flynn, J.L., Chan, J., Triebold, K.J., Dalton, D.K., Stewart, T.A. and Bloom, B.R. (1993) J. Exp. Med. 178, 2249.

[31] Kamijo, R., Shapiro, D., Le, J., Huang, S., Aguet, M. and Vilcek, J. (1993) Proc. Natl. Acad. Sci. USA 90, 6626.

[32] Xie, Q.W., Whisnant, R. and Nathan, C. (1993) J. Exp. Med. 177,1779 .

[33] Kamijo, R., Harada, T., Matsuyama, T., Bosland, M., Gerecitano, J., Shapiro, D., Le, J., Koh, S.I., Kimura, T., Green, S.J., Mak, T.W., Taniguchi, T. and Vilcek, J. (1994) Science 263, 1612.

[34] Nussler, A.K., DiSilvo, M., Billiar, T.R., Hoffman, R.A., Geller D.A., Selby, R., Madariaga, J. and Simmons, R.L. (1992) J. Exp. Med. 176, 261

[35] Nussenzweig, R.S., Vanderberg, J., Most, H. and Orton, C. (1967) Nature 216, 160.

[36] Weiss, W.R., Good, M., Hollingdale, M., Miller, L.H. and Berxofsky, I.A. (1989) J. Immunol. 143, 4263.

[37] Nussler, A.K., Renia, L., Pasquetto, V., Miltgen, F., Matile, H. and Mazier, D. (1993) Eur. J. Immunol. 23, 882.

[38] Seguin, M.C., Klotz, F.W., Schneider, I., Weir, J.P., Goodbary, M., Slayter, M., Raney, J.J., Aniagolu, J.U. and Green, S.J. (1994) J. Exp. Med. 180.

[39] Nussler, A., Drapier, J.C., Renia, L., Pied, L., Miltgen, F. Gentilini, M. and Mazier, D. (1991) Eur. J. Immunol. 21, 227.

[40] Mellowk, S., Green, S.J., Nacy, C.A. and Hoffman, S.L. (1991) J. Immunol. 146, 3971.

[41] Schofield, L., Villaquiran, J., Ferreria, A., Schellekens, H. Nussenzweig, R. and Nussenzweig, V. (1987) Nature 330, 4263.

[42] Ferreria, A., Schofield, L., Enea, V., Schellekens, H., van der Meide, P., Collins, W.E., Nussenzweig, R.S. and Nussenzweig, V. (1986) Science 232, 881. 